\title{
Study on the Opportunities and Countermeasures for the Development of Chinese Foreign Trade under the background of "Belt and Road"
}

\author{
Bing Wang ${ }^{1}$ \\ ${ }^{1}$ Nanyang Institute of Technology, Nanyang, Henan, 473004
}

Keywords: Belt and Road; foreign trade; countermeasures

\begin{abstract}
The "Belt and Road" strategy is a new channel for Chinese economic and trade cooperation between countries in the new century. It is a strategic concept for mutual trust, mutual benefit, and resource exchanges. By grasping the background and thinking of the "Belt and Road" strategy, this paper analyzes the development opportunities of Chinese foreign trade, and at the same time recognizes the obstacles in the implementation of the strategy and proposes specific countermeasures.
\end{abstract}

\section{Introduction}

The "One Belt and One Road" strategy is a good medicine for reviving the vitality of the international economy and for achieving economic transformation. It is also a strategy for building a prosperous economy along the country and regions along the route. Chinese foreign trade should make full use of the unprecedented historical development opportunities created by the "Belt and Road Initiative," increase the quality and competitiveness of enterprises, expand the pace of going abroad, increase international direct investment, and strengthen the exchange and exchange of regional factors; at the same time, it must be clear. There are still many obstacles to understanding the implementation of the "One Belt and One Road" strategy and we need to be prepared to deal with it.

\section{Implementation Obstacles of "Belt and Road"}

The original intention of the "One Belt and One Road" is to strengthen regional economy and secondly to promote regional friendship. However, in reality, most countries are cautious about Chinese opening up. On the one hand, they hope to receive more Chinese capital, technology, markets, and grants. On the other hand, they worry that further opening up will result in Economic over-reliance. There are different concerns and doubts in ASEAN, Central Asia, and Africa. How to achieve overall coordination and specific considerations in terms of updating cooperation content, expanding areas of cooperation, and enhancing trade and investment facilitation, and avoiding the "China threat theory" are the first real dilemmas faced by China [1].

The "One Belt, One Road" area is the main production area of the world's natural resources, and it is therefore given an important strategic significance. Russia, the United States, the European Union, and Japan all have their own development ideas. The United States' "New Silk Road" strategy and Japan's "New Silk Road Diplomacy" are all aimed at countering China. Russia and India also regard Central Asia and the Indian Ocean as their own traditional spheres of influence, and they are skeptical and resistant to any foreign country. This explains why, when China proposed the "Belt and Road" initiative, the international media either did not speak or made unfriendly statements.

Compared with the international cold, the "One Belt and One Road" is widely popular in China. According to incomplete statistics, no fewer than 30 cities in China have declared themselves as the starting point of the "One Belt and One Road". "Free Trade Zone," "Bridgehead," and "Integration" have all been released. All regions hope that they can be the shortest ones. In order to win the most resources in time, it is bound to face an overall coordination problem. Unfortunately, no matter whether it is the national level of regulation and control, or cross-regional or inter-departmental 
cooperation and coordination agencies have not yet been established, the coordination mechanism is not clear, the real implementation of the "Belt and Road" initiative must first address the issue of how to balance the rights and interests of various provinces and municipalities. Therefore, from a realistic point of view, both the speed of implementation and the difficulty of implementation need to be solved in time.

The "One Belt and One Road" concept is an open economic development strategy. Its core idea is to develop the economy. If so, then the main body should be the enterprise. The ideal goal is: The government sets up a stage and the company sings. The government, through investment promotion, improved infrastructure and vigorously promoted local enterprises to go abroad. This requires domestic companies to have a leading economic sense, reach a consensus with international values, and fundamentally enhance their international operating capabilities. However, the actual situation is that domestic enterprises lack a thorough understanding of the rules of trade liberalization, and the driving of interests causes the trade friction to show a trend of normalization and complication, and it is not good for Chinese enterprises to seize opportunities, seize opportunities, develop resources, and expand business opportunities. Short board exposed

\section{Opportunities for Chinese Foreign Trade under the "Belt and Road" Strategy}

Through the signing of a series of economic and trade cooperation framework agreements and specific cooperation programs, the economic and trade cooperation between China and the countries along the route has a clear blueprint for development. The spirit of mutual benefit and mutual trust inspires Chinese closer economic and trade relations with countries along the route. The countries along the route proceed from their own development and enthusiastically respond to the "Belt and Road Initiative." The willingness to accept and cooperate with each other also brings a broader market and development space [2].

The measures taken by the countries along the Belt and Road to improve the conditions of customs clearance facilities and the implementation of trade facilitation clauses have made it easier for foreign trade companies in China to go out and have lower trade costs. This will help improve the overseas of Chinese enterprises. Competitiveness increases opportunities for participation in international competition.

The "Belt and Road" strategy has opened up a broader market and cultivated a suitable soil for the innovation of trade methods. The new format companies represented by the Internet have great room for development under the opportunity of the "Belt and Road" initiative. The freedom, convenience, and speed of the Internet coincide with the openness of the "Belt and Road Initiative." The development of e-commerce will continue to grow, the threshold for foreign trade will continue to decrease, and the level of Chinese opening will continue to deepen.

The technology accumulated by Chinese long-term hard work will soon be a big deal. There is a high-speed railway before it, followed by the world's fastest quantum computer and a large commercial aircraft of China. Undoubtedly, these advanced science and technology will enter the international market more smoothly under the historical opportunity of the "One Belt and One Road” strategy and participate more in the international market competition. Made in China will create a shift to China.

With the implementation of the "One Belt and One Road" strategy, large amounts of investment in infrastructure and other construction projects require large amounts of capital. China has launched Asian Infrastructure Investment Bank and related funds, but there is still a large funding gap [3]. This will encourage the countries along the route to carry out more financial innovations. On the one hand, it will contribute to its domestic economic development. On the other hand, it will also help increase the efficiency of its capital use, increase its import capacity, and increase its import demand. It will also help promote foreign trade. development of.

Traffic is very important for the development of regional economy. Convenient transportation includes railways, highways, aviation, and shipping. The "One Belt and One Road" strategy plans to rely on the international macro channel on land and rely on key ports on the sea to create a safe and smooth major channel. It can be seen that the "One Belt and One Road" strategy is extremely 
convenient for transportation and will greatly promote the development of Chinese foreign trade.

\section{Measures to Implement the "Belt and Road" Initiative}

In the development of the "One Belt and One Road," we must boldly learn from the experiences of developed countries, make full use of international rules of the game, foster the ideas of big countries, dare to try, and be bold in innovation. It should be noted that the "One Belt and One Road" strategy is to replace resources with resources, replace advantages with advantages, and make up for each other with different economic endowments. As an economic power, we must take a long-term view and place the definition of strategic swaps in an infinite space and time so as to seek a more far-reaching win-win situation. To be implemented, the first is to lower tariffs and relax investment in the investment field. Second, we must strengthen the construction of the legal system so that it is open and fair. Finally, it is to adopt proactive and active strategic adjustments to create a favorable opening pattern and a favorable flexible development space for itself. . The world and China are interdependent, and instead of waiting passively for the world to embrace us, it is better to give priority to opening up resources, opening up markets, and opening up investment. When you come to me, you can continuously adjust your strategies, take what you need, and achieve mutual benefits. What is a reasonable rule? Each country's playing in accordance with chapters and playing cards according to chapters is a common rule. In the process of developing the "Belt and Road", China needs to sign different agreements with different countries. This is a process of continuously creating rules. Our country must firmly safeguard reasonable international trade rules and actively participate in the revision and formulation of international trade rules. Judging from past experience, the rule-makers are often the winners of the final interests. Therefore, we must actively participate in the formulation of various trade rules and maximize its development in a reasonable direction so that the rules can reflect internationally in an objective and fair manner [4]. The real situation of trade will win more benefits for our country and increase our influence in international trade. In terms of strategic layout, all activities should be implemented in accordance with the principles of bilateral breakthroughs, multilateral flowering, peripheral priorities, and near and far, one mature and one development. To this end, we can extend the current negotiations and upgrade existing cooperation agreements. In the course of joint negotiations, bilateral pipelines and regional cooperation platforms can be launched to carry out a package of cooperation in specific areas. Under the premise of mutual benefit and win-win results, the "Silk Road Countries" will be given some care to improve the self-sufficiency ability of Chinese economy. For example, the construction of the "Silk Road Economic Belt" is focused on the construction of access roads. To this end, all regions should speed up the construction of basic transport facilities, constantly improve the construction of transportation networks such as roads and railways, and improve the construction of transit transport facilities and border cargo transit as soon as possible. Station; in the trade and investment facilitation, actively promote the Sino-Ukraine, China-Kazakhstan trade cooperation on the border; In addition, in the monetary and financial cooperation, bilateral personnel are provided with certain convenience, even legal and policy support, to optimize the implementation of the strategic layout.

First of all, we must make it clear that economic diplomacy has become the country's most important form of diplomacy and must be incorporated into the country's overall development strategy [5]. We must know that the "One Belt and One Road" is not only a national economic and trade cooperation, but also a national implementation of diplomacy. A new form whose implementation effect is related to Chinese economic development and national defense security, such as rising to the national strategic level of economic security. In the specific implementation process, various implementation plans shall be planned and implemented in a solid manner. The State Council, various ministries and commissions, and local governments and other administrative departments shall be responsible for the implementation and supervision. Second, mobilize the enthusiasm of Chinese enterprises, chambers of commerce, and guilds to promote professional guidance in international trade negotiations. The essence of the "One Belt and One Road" is mutual benefit, which is consistent with the business objectives of the enterprise. The chamber of 
commerce and guild are representatives of the company and can communicate with the government to balance the interests of different industries in the negotiation; in addition, they can also stand Different angles provide the government with trade consultation, foreign market research information, and professional negotiation techniques. Based on the above reasons, the government should give the chamber of commerce and guilds more market space, and ensure that its initiative and enthusiasm can be fully utilized in space and time. Finally, encourage Chinese enterprises to actively participate in economic and trade negotiations. When companies go out of the country and enter the international market, they are no longer independent individuals. Once they encounter unfair treatment in the course of business operation, they should seek assistance from the government and reduce trade activities that violate bilateral agreements or WTO agreements. The losses brought to the enterprise; and the government departments that are backed by the enterprise, once they encounter help from the enterprise, they should exert their organizational capabilities, firmly support and protect the legitimate rights and interests of the enterprise, and make the enterprise take initiative to assume its own responsibility. It is also very important to correctly guide the mainstream media and play a positive and positive role for the media. "One Belt and One Road" is not only a way to win-win cooperation, but also a game field where advantages are mutual. With the continuous development of modern communication technology, the speed of information dissemination is getting faster and faster, and the influence of public opinion and public opinion continues to rise. This places higher demands on modern economic and trade activities. Government departments and enterprises should strengthen public relations with the media to reduce the occurrence of misreading, misjudgment, or false positives caused by the inaccurate or inaccurate transmission of information. At the same time, they can avoid public opinion pressure caused by misrepresentation reports from affecting our country. Chinese foreign trade negotiations ensure that our government will always take the initiative in negotiations.

\section{Conclusion}

As a strategic concept for in-depth international cooperation in the new century, the "One Belt and One Road" strategy has created a golden opportunity for Chinese foreign trade enterprises. At the same time, the "One Belt and One Road" strategy is also facing some problems and impediments. These obstacles also affect Chinese foreign trade. To overcome these obstacles, it is necessary for our foreign trade enterprises to strive to improve their own corporate quality and product competitiveness, as well as to increase their legal awareness and legal capabilities. At the same time, they must increase direct investment in foreign countries and reduce costs. They also need the government to strengthen policy coordination and provide policies. Support and promote the further development of Chinese foreign trade.

\section{References}

[1] Dong Hong, Lin Huihui. Chinese Foreign Trade Pattern Change and Trade Friction Guard under the "One Belt and One Road" Strategy [J]. Chinese Circulation Economy, 2015(5).

[2] Wu Yusheng. Several Problems of the "One Belt One Road” Strategy Thinking [J]. China Development Observations, 2015(6).

[3] Guo Zhouming. Predicament of Chinese Foreign Trade in the New Situation and Countermeasures [J]. Contemporary Finance, 2013(5).

[4] He Maochun, Zhang Yubing, Zhang Yajun, Tian Bin. Obstacles and Countermeasures of the “One Belt and One Road” Strategy[J]. Journal of Xinjiang Normal University (Natural Science Edition),2015(03).

[5] Guo Ming, Feng Yiqiang. How to implement the "One Belt and One Road" major strategy [J]. Journal of Changchun Institute of Education, 2015(08). 